\title{
A DIMENSÃO DAS PRÁTICAS SOCIAIS DO JORNALISMO MÓVEL: os impactos do uso de smartphones na rotina produtiva dos jornalistas
} THE SOCIAL PRACTICES DIMENSION OF MOBILE JOURNALISM: the consequences of using smartphones on the journalist's work

routine

\author{
Alice Oliveira de ANDRADE ${ }^{1}$ \\ Itamar de Morais NOBRE ${ }^{2}$ \\ Maria do Socorro Furtado VELOSO 3 \\ Universidade Federal do Rio Grande do Norte | Brasil
}

\begin{abstract}
Resumo
Neste artigo, objetiva-se analisar o jornalismo móvel a partir da dimensão das práticas sociais, observando os impactos causados pelo uso de dispositivos móveis digitais (DMDs) nas rotinas produtivas de duas redações de Natal - RN. Como resultado, identifica-se um conjunto de consequências descritas a partir de quatro categorias de análise: jornalista polivalente, níveis de conteúdo, abertura dos canais informacionais e jornalismo de redação. Como abordagem metodológica, propõe-se a construção de uma cartografia simbólica (SANTOS, 2011). O referencial teórico inclui Silva (2013; 2015; 2016), Satuf (2015), Santos (2011), Jorge, Pereira e Adghirni (2009) e Salaverría e Negredo (2008).

Palavras-chave

Jornalismo móvel digital; Jornalistas polivalentes; Rotinas produtivas; Práticas sociais. Estudos da mídia.

\section{Abstract}

This article aims to analyze mobile journalism from the dimension of social practices, observing the impacts caused by the use of digital mobile devices (DMDs) in the productive routines of two newsrooms in Natal, Rio Grande do Norte. As a result, we identify a set of consequences described from four categories of analysis: multipurpose journalist, content levels, opening of information channels and newsroom journalism. As a methodological approach, the construction of a symbolic cartography is proposed (SANTOS, 2011). The theoretical framework includes Silva (2013; 2015; 2016), Satuf (2015), Santos (2011), Jorge, Pereira and Adghirni (2009) and Salaverría and Negredo (2008).

Keywords

Digital mobile journalism; Polivalent journalists; Productive routines; Socia practices; Media studies.
\end{abstract}

RECEBIDO EM 25 DE MARÇO DE 2021

ACEITO EM 05 DE JULHO DE 2021

${ }_{1}^{1}$ Doutoranda e mestra pelo Programa de pós-Graduação em Estudos da Mídia da Universidade Federal do Rio Grande do Norte (PPgEM/UFRN). Bacharel em Comunicação Social - Jornalismo pela mesma instituição. Integra o grupo de pesquisa Pragmática da Comunicação e da Mídia (PRAGMA-CNPq). Contato: aliceandrade@live.com.

${ }^{2}$ Docente do Programa de Pós-Graduação em Estudos da Mídia (PPgEM) e do Departamento de Comunicação Social (Decom) da Universidade Federal do Rio Grande do Norte. Integra o Grupo de Pesquisa Epistemologias e Práticas Emergentes e Transformadoras em Comunicação, Mídias e Cultura (Ecomsul/UFRN).

3 Docente do Programa de Pós-Graduação em Estudos da Mídia (PPgEM) e do Departamento de Comunicação Social (Decom) da Universidade Federal do Rio Grande do Norte. Integra os grupos de pesquisa Pragmática da Comunicação e da Mídia (PRAGMA-CNPq) e Epistemologias e Práticas Emergentes e Transformadoras em Comunicação, Mídias e Cultura (Ecomsul/UFRN). Contato: socorroveloso@uol.com.br

João Pessoa - Brasil | ANO 8 VOL.8 N.1 | JAN./JUN. 2021 | p. 13 a 31

Revista Latino-americana de Jornalismo | ISSN 2359-375X

Programa de Pós-Graduação em Jornalismo - UFPB

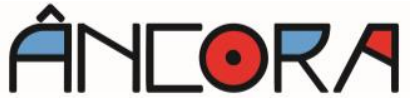




\section{ÂNEORA}

Alice ANDRADE - Itamar NOBRE - Maria Veloso

\section{Introdução}

chamada mobilidade digital vem modificando os rumos da prática
jornalística de maneira estrutural, o que demanda a necessidade
de atenção às consequências dessas transformações, não somente na perspectiva técnica, mas também humana. Partindo deste pressuposto, objetiva-se, com este artigo, apresentar os resultados de estudo 4 acerca dos impactos sociais causados pelo uso de dispositivos móveis digitais na rotina produtiva de jornalistas em redações da cidade de Natal, no Rio Grande do Norte. Buscou-se responder ao seguinte questionamento: no âmbito da produção jornalística, a quem servem as tecnologias móveis?

Como pistas gerais, verifica-se, de um lado, que as empresas jornalísticas adotam as tecnologias digitais como forma de atender às demandas por inovação, paralelamente à redução de custos. Por outro, exigese dos jornalistas um perfil cada vez mais multitarefa e produtivo, mas sem a necessária compensação remuneratória. Dentre as possibilidades de enfoque desse cenário, este artigo toma por base as dimensões do jornalismo móvel digital proposta por Silva (2016) visando a contemplar a dimensão das práticas sociais do jornalismo móvel, que enxerga consequências para os profissionais do ponto de vista laboral.

Fidalgo e Canavilhas (2009) lembram que os telefones móveis são meios privilegiados de comunicação e, ao mesmo tempo, impõem desafios ao jornalismo, considerando-se que esses aparelhos permitem 0 acesso às informações em qualquer hora e local. "O celular, ao tornar-se uma extensão corporal, liberta a pessoa dos constrangimentos espaciais e temporais na

\footnotetext{
${ }^{4}$ Este trabalho é um recorte de pesquisa de dissertação defendida no Programa de Pós-Graduação em Estudos da Mídia da Universidade Federal do Rio Grande do Norte (PPgEM/UFRN), em fevereiro de 2018, com título: "Cartografia da mobilidade jornalística: os impactos do uso dos dispositivos móveis digitais na rotina de produção do jornalista em Natal (RN/Brasil)".
} 
recepção de informação" (FIDALGO; CANAVILHAS, 2009, p.112). A ergonomia dos smartphones permite tanto aos jornalistas quanto ao público dos jornais uma forma mais íntima de lidar com as notícias, uma vez que o fato de serem portáteis permite que sejam levados para diferentes espaços físicos, mantendo, ainda, a possibilidade de conexão à internet.

Assim, ao mesmo tempo que possibilitam a agilidade do trabalho jornalístico - devido à característica multifuncional e à possibilidade de conexão em rede - os dispositivos móveis digitais impõem importantes modificações no perfil profissional almejado pelo mercado. A distribuição multiplataforma do conteúdo foi adotada como estratégia de negócios das empresas jornalísticas e tem provocado consequências diretas para as rotinas de produção e organização das redações. Os jornalistas, enquanto trabalhadores inseridos nesse ambiente de constante convergência, são pressionados a dominar distintas linguagens e formas de produção e divulgação.

Neste estudo, adotamos predominantemente o termo "jornalismo móvel digital" (SILVA, 2013) para a referência a esse fenômeno, por compreendermos que a nomenclatura representa mais adequadamente a realidade encontrada em nosso campo empírico de pesquisa. Os termos "jornalismo móvel" e mojo ("mobile journalism") serão encontrados ao longo do texto como forma de variação lexical.

Metodologicamente, desenvolve-se uma cartografia simbólica (SANTOS, 2011), na qual é possível construir mapas sociais a partir de um olhar crítico sobre determinada realidade e com obtenção de dados através de técnicas de investigação como a pesquisa bibliográfica, entrevista e observação nãoparticipante. Nessa metodologia, a simbolização do mapa pode ser conceitual, aqui representado pelos marcadores obtidos nos resultados: jornalista polivalente, níveis de conteúdo, abertura dos canais informacionais e jornalismo de redação. Como título interpretativo, chamamos de cartografia da mobilidade jornalística o mapeamento simbólico construído neste trabalho de

João Pessoa - Brasil | ANO 8 VOL.8 N.1 | JAN./JUN. 2021 | p. 13 a 31 


\section{ÂNEORA}

Alice ANDRADE - Itamar NOBRE - Maria Veloso

pesquisa. Para tecer o diálogo teórico, o artigo contempla reflexões de Silva (2013; 2015; 2016), Satuf (2015), Santos (2011), Jorge, Pereira e Adghirni (2009) e Salaverría e Negredo (2008).

\section{Jornalismo móvel e a dimensão das práticas sociais}

Em perspectiva histórica, o jornalismo móvel está relacionado ao avanço da microeletrônica e das telecomunicações, a partir dos anos 1970, e da popularização do computador pessoal, nos anos 1990 (SILVA, 2015). Por volta de 2005, o termo mojo passou a nomear o repórter que, em sua prática de campo, utiliza ferramentas do telefone celular para a produção e disseminação de conteúdos jornalísticos. Em uma produção com aparatos tecnológicos móveis feita a partir do local do acontecimento, as audiências podem acompanhar a construção de uma narrativa ao vivo ou em poucos minutos após ocorrido.

No contexto do jornalismo, a palavra MoJo parece ter sido cunhada por funcionários dos jornais Gannett nos EUA em 2005. Era o nome código para um projeto do The News-Press em Fort Myers, na Flórida, em que os repórteres estavam se reunindo e distribuindo notícias de novas maneiras, embora a maioria dos repórteres use ainda laptops e câmeras portáteis (QUINN, 2014, p.84).

O jornalismo está hoje intrinsecamente ligado à mobilidade digital, 0 que leva a produção e o consumo dos conteúdos jornalísticos em plataformas móveis a configurarem um novo ecossistema (SILVA, 2016). As empresas investem na inovação tecnológica em seus modelos de negócios para acompanhar o fluxo do público ansioso por informação cada vez mais ubíqua; por outro lado, seguem priorizando a ampliação dos lucros e/ou redução dos custos, considerando sua inserção nos modos capitalistas de produção.

A mobilidade digital foi determinante para a instantaneidade e celeridade na difusão de notícias. Criou-se um novo potencial de produção, e a relação entre público-empresas de comunicação está vinculada a um canal de mão-dupla, no qual os conteúdos de caráter jornalístico não apenas são 
emitidos, como também pode haver uma postura ativa do receptor no processo de produção. Se a mídia é parte da textura geral da experiência humana (SILVERSTONE, 2002), os dispositivos móveis digitais reforçam a centralidade midiática por meio da ubiquidade do ecossistema informacional.

Esse contexto híbrido de inserção de aparatos tecnológicos em todas as etapas de produção, distribuição e consumo do jornalismo provoca transformações. A fluidez com que as mudanças ocorrem ultrapassam a compreensão do transporte da informação para um sistema binário, pois essa new thing (SCOLARI, 2008) impulsiona desdobramentos da forma como o jornalismo é produzido hoje.

Paradoxalmente à discussão sobre globalização e seus fluxos informacionais mundializados frente ao encurtamento do tempo e das distâncias, o jornalismo móvel é também prática hiperlocal, visto que a produção e distribuição dos materiais jornalísticos podem ser feitas exatamente do local geográfico onde o fato acontece. Desliga-se do processo jornalístico cíclico (apuração-produção-divulgação) a necessidade de estruturas físicas não-portáteis, propiciando uma reconfiguração da ideia de "lugar" ao público por meio da utilização de tecnologias móveis digitais, as quais potencializam elementos de geolocalização e permitem a exploração de aspectos sensoriais, como imagens e som em tempo real (SILVA, 2015, p.35).

Novos elementos ganham a possibilidade de ser explorados na narrativa jornalística, em especial pelos suportes oferecidos na conexão que permite 0 acesso a redes sociais virtuais. Cria-se um novo ecossistema em que o conteúdo das empresas de comunicação é produzido e também consumido por meio dos dispositivos móveis. Para Satuf (2015, p.444), denomina-se jornalismo móvel:

Um conjunto de práticas de produção, edição, circulação e consumo de conteúdos jornalísticos em dispositivos portáteis digitais que agregam conexão ubíqua, conteúdos por demanda adaptados ao contexto do usuário e integração de múltiplos formatos midiáticos.

João Pessoa - Brasil | ANO 8 VOL.8 N.1 | JAN./JUN. 2021 | p. 13 a 31

Revista Latino-americana de Jornalismo | ISSN 2359-375X

Programa de Pós-Graduação em Jornalismo - UFPB

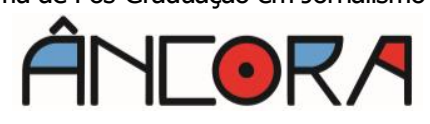




\title{
ANICORA
}

Alice ANDRADE - Itamar NOBRE - Maria Veloso

O conceito de jornalismo móvel digital se vincula à exploração de novos formatos adequados ao ambiente da internet móvel e dos dispositivos móveis digitais. A transposição de conteúdos jornalísticos originalmente divulgados em plataformas impressas para as digitais nem sempre é adequada às expectativas e necessidades do público. O meio digital propicia potencialidades que envolvem linguagens e instrumentos exclusivos, como o hipertexto. As técnicas de escrita podem ser associadas a elementos multimidiáticos, como fotos, vídeos e infográficos. A "pirâmide invertida" deixa de ser regra primordial para a produção do texto informativo. Ou seja, o espaço para a criatividade do jornalista é ampliado por não estar mais limitado ao suporte de papel.

$\mathrm{O}$ acesso à internet por meio das redes 3G, o desenvolvimento de software aplicativos e de aparelhos com novas funcionalidades em hardware intensificaram e consolidaram o jornalismo móvel, na primeira década do século 21 . As redes $4 \mathrm{G}$ e wifi ampliam ainda mais as possibilidades de conexão à internet a partir de dispositivos móveis ${ }^{5}$. Neste contexto, Silva (2015) pensa o jornalismo móvel também no âmbito da produção:

\begin{abstract}
A utilização de tecnologias móveis digitais e de conexões de redes sem fio pelo repórter na prática jornalística contemporânea visando ao desenvolvimento das etapas de apuração, produção e distribuição de conteúdos do campo ou de transmissão ao vivo [...] jornalismo móvel digital incorpora o "móvel" de mobilidade e o "digital" da digitalização do aparato técnico utilizado para conferir um rearranjo às rotinas produtivas no jornalismo e ao consumo de notícias (SILVA, 2015, p.11).
\end{abstract}

O dispositivo móvel digital permite a configuração de uma redação deslocada do ambiente físico. Goggin (2006) observa que a cultura do celular associa portabilidade, personalização e mobilidade às novas formas de

\footnotetext{
5 Segundo o Instituto Brasileiro de Geografia e Estatística (IBGE), há uma tendência de crescimento da banda larga móvel (3G/4G) com 80,2\% dos usuários. Disponível em: $<$ https://www.terra.com.br/noticias/dino/acesso-a-internet-cresce-mas-um-em-cada-quatro-brasileirosainda-permanece-desconectado,7343ed8475bbce8fad5031e1a1f2b96efthz4zm3.html>. Acesso em: 18 mar. 2021.
} 
conduzir a vida em inúmeros aspectos, tais como educação, negócios, serviços e nas relações pessoais. No jornalismo, a prática de campo tem se reconfigurado com o uso de tecnologias digitais em contexto de mobilidade (SILVA, 2013).

Assim, entendemos que a prática do jornalismo móvel digital, com ênfase no trabalho empírico realizado pelos jornalistas, é desenvolvida em um ciclo de produção móvel composto por três referenciais: apuração, produção e distribuição. Nesta pesquisa, o eixo da circulação não foi parte do corpus analítico.

O jornalismo móvel se configura na execução de uma, duas ou de todas essas etapas por meio de dispositivos móveis digitais conectados à internet. $\mathrm{A}$ apuração consiste, em termos práticos, em atividades como a gravação de entrevistas em áudio, vídeo, notas de texto ou contato com as fontes - para marcação ou execução de entrevistas ou curadoria de informações - por meio de aplicativos de redes sociais virtuais. O referencial da produção diz respeito ao refinamento da coleta de dados feita na apuração, objetivando a elaboração de conteúdos de caráter jornalístico. O passo seguinte é a disseminação desse(s) produto(s), tendo como ponto de partida outras tecnologias móveis, em plataformas que podem ser tanto impressas como digitais - incluindo sites, jornais, programas de televisão ou rádio, redes sociais na internet ou aplicativos voltados para a atividade jornalística.

Nos referenciais da apuração e produção, todas as operações podem ser realizadas sem haver a necessidade de conexão à internet - embora sejam necessários aparatos digitais para a produção de conteúdo, como um computador, câmera fotográfica ou um gravador, por exemplo. Contudo, para a distribuição, a ausência de acesso à internet comprometerá a repercussão do produto jornalístico final junto ao público. Dessa forma, a conexão pelo aparelho é fundamental para a concretização do ciclo de produção móvel.

João Pessoa - Brasil | ANO 8 VOL.8 N.1 | JAN./JUN. 2021 | p. 13 a 31 


\section{ANIEORA}

Alice ANDRADE - Itamar NOBRE - Maria Veloso

Silva (2016) reflete a respeito da existência de uma cultura do jornalismo móvel na atualidade, devido ao aumento do uso de dispositivos móveis nas redações jornalísticas e do consequente desenvolvimento de práticas e narrativas associadas a essa reestruturação. Na última década, a relação entre jornalismo e tecnologias móveis digitais se estreitou. Levando em consideração apenas a produção, essa associação ocasionou a diversificação dos produtos e o modo de fazer e distribuir o conteúdo, pois, ao longo do tempo,

[...] o jornalismo móvel foi se consolidando como prática e hoje podemos indicar quatro dimensões delimitadas para podermos refletir: 1. Dimensão da produção jornalística; 2. Dimensão do Consumo; 3. Dimensão da convergência/ multiplataforma; 4. Dimensão da mobilidade expandida (SILVA, 2016, p. 153).

Sobre a primeira dimensão, o autor se refere ao aspecto físico da produção e distribuição jornalística em contexto de mobilidade, como smartphones ligados à internet e redes sem fio de caráter híbrido e ubíquo. $\mathrm{Na}$ segunda, trata-se do acesso aos conteúdos informativos por meio de aplicativos em software em aparatos móveis digitais. A terceira vincula as dimensões já citadas, pois a produção e o consumo de notícias e demais produções informativas estão diretamente ligadas a um ecossistema convergente tanto no aspecto físico dos dispositivos quanto aos produtos jornalísticos convergentes, além da multiplicidade de suportes midiáticos envolvidos nesse processo. Já a quarta dimensão se refere à expansão do uso desses dispositivos, em razão da nova perspectiva que o jornalismo estabelece em sua relação com a tecnologia, como é o caso, a título de exemplo, da realidade virtual e das tecnologias vestíveis.

Essas dimensões são significativas para a compreensão do contexto no qual o jornalismo está inserido no século XXI. Por não ser um campo homogêneo, o jornalismo móvel amplia as possibilidades de apropriação dessas tecnologias ubíquas e causa desdobramentos nas dimensões citadas 
por Silva (2016). Entretanto, como foco para esta análise, propomos o acréscimo de uma quinta dimensão: das práticas sociais.

Esta dimensão visa problematizar os impactos e tensionamentos causados pela cultura do jornalismo móvel para o jornalista com a penetração das tecnologias digitais nas rotinas produtivas, dando margem à reflexão sobre os reordenamentos nas suas condições de trabalho a partir da produção em ecossistema móvel, bem como as consequências dessas novas práticas para a qualidade do produto jornalístico. Embora a análise dos aspectos técnicos seja indissociável em quaisquer estudos da área, é na dimensão das práticas sociais do jornalismo móvel que está o foco desta pesquisa.

O jornalismo impresso cultivou uma audiência específica para seus objetivos centrais: pelo texto, fotografia e outros recursos de edição, informar. Com o passar do tempo, porém, os jornais precisaram se adaptar ao novo contexto, como veremos a seguir.

\section{Os impactos do uso de dispositivos móveis digitais na rotina produtiva dos jornalistas}

Para investigar esse contexto sob a ótica das práticas sociais, os procedimentos metodológicos incluíram a construção de uma cartografia simbólica (SANTOS, 2011) que contemplou duas empresas jornalísticas de Natal - RN: a Tribuna do Norte e o Novo Jornal. Para a coleta de dados, foram realizadas entrevistas e observação não-participante com o acompanhamento da rotina produtiva dos jornalistas dessas empresas durante uma semana. Ao todo, realizamos 54 entrevistas com os profissionais, entre jornalistas e fotógrafos que produzem conteúdo para as plataformas digital e impressa. 0 foco das perguntas foi a rotina laboral e as condições de trabalho desde o uso frequente de smartphones para a produção jornalística.

Compreendidos como uma "cartografia da mobilidade jornalística", os resultados da pesquisa foram apresentados pela simbolização conceitual de

João Pessoa - Brasil | ANO 8 VOL.8 N.1 | JAN./JUN. 2021 | p. 13 a 31

Revista Latino-americana de Jornalismo | ISSN 2359-375X

Programa de Pós-Graduação em Jornalismo - UFPB

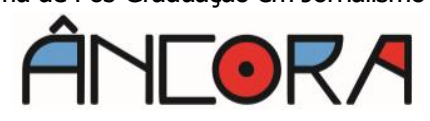




\section{ANILORA}

Alice ANDRADE - Itamar NOBRE - Maria Veloso

práticas que se convencionalizaram a partir do uso dos smartphones pelos repórteres, que também representam as categorias de análise: o jornalista polivalente, os níveis de conteúdo, a abertura dos canais informacionais e o jornalismo de redação.

$\mathrm{Na}$ investigação realizada nas redações natalenses, percebeu-se que a partir de 2015, após a introdução dos smartphones nas rotinas de trabalho dos jornalistas, houve uma redução do quadro profissional. No Novo, a função de pauteiro foi eliminada em 2015 e ficou sob responsabilidade dos demais profissionais. O número de fotojornalistas, de 2014 para 2017, foi reduzido de cinco para um. Este enxugamento do quadro acarretou em acúmulo funcional para os repórteres, que passaram a apurar as pautas e a produzir as fotografias nos próprios smartphones. Já na Tribuna do Norte, havia três fotógrafos contratados para sete repórteres, fazendo com que estes precisassem cobrir as pautas solitariamente, em muitas ocasiões. De fato, como constata Fígaro (2013, p. 7), "as mudanças tecnológicas apropriadas no fazer jornalístico redesenharam as maneiras de se trabalhar. As redações ganharam outro formato, outro ritmo, muitas profissões desapareceram".

Com a apropriação dos dispositivos móveis digitais pelas empresas jornalísticas, profundas reconfigurações aconteceram nas rotinas produtivas dos profissionais (SILVA, 2013), causando, consequentemente, impactos não apenas para as condições de trabalho, mas também na qualidade e formato dos produtos jornalísticos. Na construção desta pesquisa cartográfica, as categorias de análise são as simbolizações, criadas com base em comportamentos que se repetem a partir do uso de smartphones no cotidiano de trabalho: a) O jornalista polivalente; b) Os níveis de conteúdo; c) A abertura dos canais informacionais; d) $O$ jornalismo de redação. $A$ respeito desses pontos, trataremos a partir de agora.

a) O jornalista polivalente: 
Manhã de trabalho, pautas para cumprir. Nos bolsos da calça, apenas três instrumentos de trabalho: o bloquinho, a caneta e o smartphone, adquirido pela empresa em 2017. O jornalista parece carregar menos peso, se comparado ao perfil de trabalho da década passada, quando às vezes, além do tradicional bloco de papel e lápis, precisava da câmera fotográfica, mapa, agenda telefônica, gravador de áudio e cartão de memória. A leveza dos equipamentos no bolso combina com o contracheque ao final do mês: o jornalista polivalente trabalha mais, mas seu salário não aumentou.

Esse profissional precisa executar várias funções simultaneamente. Com o smartphone, grava a entrevista, filma, faz anotações, fotografa e gerencia as redes sociais na internet. Em algumas ocasiões, ainda utiliza o aparelho para providenciar o próprio transporte, uma vez que o jornal já não tem motoristas em seu quadro. No caminho entre uma pauta e outra, aproveita para agendar uma entrevista para o dia seguinte, no WhatsApp. Sob o manto da inovação tecnológica e da criatividade, chega a dobrar a carga horária de trabalho e também a quantidade de funções que desempenha, para tentar garantir seu espaço no mercado. A partir dessa paisagem, obtida com a observação não-participante, é possível entender que este novo perfil profissional é cada vez mais valorizado:

O profissional do jornalismo que as empresas estão buscando é mesmo o superjornalista, o hiperjornalista. Em entrevistas com profissionais das redações, as características apontadas para 0 jornalista dos dias atuais envolvem desde "dar conta de várias tarefas a um só tempo" até ter domínio de pelo menos uma língua estrangeira, demonstrar sólida bagagem cultural, gostar de tecnologia e, naturalmente, "saber onde está a notícia; ter domínio do idioma português e trabalhar com rapidez" (JORGE; PEREIRA; ADGHIRNI, 2009, p.15).

A polivalência funcional faz parte de um macrocontexto de convergência jornalística denominada por Salaverría e Negredo (2008) como a terceira esfera, a dimensão profissional. De acordo com os autores, atualmente os jornalistas têm assumido tarefas simultâneas que antes eram 


\section{ANTERA}

Alice ANDRADE - Itamar NOBRE - Maria Veloso

realizadas por mais de um profissional. O jornalista deve se adaptar a essa realidade, mesmo sem compensação salarial para essas atividades. Neste estudo, considera-se que a polivalência é estimulada pelos DMDs (dispositivos digitais móveis) porque os profissionais têm à disposição ferramentas híbridas de trabalho, como smartphones e tablets. É o que apontam os relatos abaixo:

Acho que a gente ganhou uma obrigação a mais e sem nenhum acréscimo financeiro, sem nenhuma especialização, porque a gente não passa por nenhum curso e eu acho que a empresa deveria dar essa especialização. Se você vai produzir imagem em vídeo, eu não sou especializado nisso, então é complicado. É um acúmulo de trabalho mesmo. Sua apuração fica defasada, sua escrita fica defasada, porque além de ir fazer uma matéria, entrevistar todo mundo, apurar, escrever, o cara ainda tem que se preocupar em tirar foto, fazer vídeo, postagem pro Facebook etc (Jornalista do Novo, informação verbal).

Atrapalha tanto na produção de conteúdo em si quanto se perde financeiramente. $O$ jornal poderia estar pagando um fotógrafo, mas ele economiza, coloca a gente pra fazer e ganha em cima. É uma tendência de mercado que o jornalista faça mais coisas, mas não é uma tendência de mercado que se pague o mesmo salário de antes por isso (Jornalista da Tribuna do Norte, informação verbal).

Desses relatos, é possível depreender que o jornalista polivalente está imerso em um cenário de tensões. A dimensão multitarefa pode ter aspectos positivos, visto proporcionar, ao profissional, possibilidades de produção do conteúdo e o domínio do próprio ciclo de produção. Ou seja, por um lado, os aparatos digitais e móveis potencializam o processo produtivo. Por outro, a polivalência traz prejuízos ao jornalista, pois a rotina produtiva está mais sobrecarregada e precária. A estima pela profissão e a necessidade remuneratória os fazem ceder à racionalidade instrumental. Submetido à constante flexibilização das condições de trabalho, o jornalista polivalente cumpre suas pautas na rapidez exigida pelas chefias, pois tem seu instrumento principal de trabalho na palma das mãos.

b) Os níveis de conteúdo:

O jornalismo móvel digital possibilita o desenvolvimento de estratégias de trabalho para o jornalista devido, principalmente, à característica híbrida 
dos smartphones. Consideramos que algumas delas são potencializações, como a exploração da interatividade sensorial e a hipertextualidade. Já outras representam significativas rupturas em relação ao modelo tradicional de jornalismo produzido em meios impressos, como a quebra das limitações espaciais. Em outras palavras, o repórter não está mais limitado a produzir para uma ou duas páginas de jornal, por exemplo. As multiplataformas digitais viabilizam um espaço bem mais amplo, que pode ser preenchido não apenas por texto, mas também por vídeos, áudios, infográficos, imagens, entre outros elementos. Esse ponto está relacionado tanto ao uso de dispositivos móveis digitais quanto a quaisquer outras atividades jornalísticas desenvolvidas no ciberespaço.

Portanto, os níveis de conteúdo se referem à possibilidade de atualização continuada dos conteúdos publicados em plataformas digitais. Nas empresas cartografadas, percebeu-se que a busca pela instantaneidade estimula os jornalistas a publicarem as notícias por partes, sofrendo alterações sempre que novas informações são obtidas.

Na Tribuna do Norte, observou-se a prática dos flashes: o repórter, durante a apuração externa, envia para o grupo da redação no WhatsApp as informações iniciais coletadas no momento em que chega ao local do acontecimento. Dessa forma, a notícia já é gerada no site, mesmo que não se tratem de informações completas. Conforme novos dados chegam, o texto é atualizado, fazendo com que o conteúdo seja produzido em níveis de aprofundamento. De acordo com os editores, os flashes não comprometem a qualidade da informação, mas sim auxiliam o público a obtê-la da maneira mais célere possível, como é possível perceber no depoimento de um dos editores:

O repórter, quando chega no local, não faz a apuração de qualquer jeito. Tem que falar com fontes oficiais. Obviamente que informação inicial, não é que seja errada, mas é um pouco superficial. Nós temos todo o cuidado e checamos a informação para que ela não

João Pessoa-Brasil | ANO 8 VOL.8 N.1 | JAN./JUN. 2021 | p. 13 a 31

Revista Latino-americana de Jornalismo | ISSN 2359-375X

Programa de Pós-Graduação em Jornalismo - UFPB

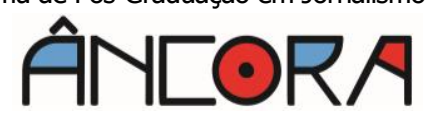




\section{ÂNEORA}

Alice ANDRADE - Itamar NOBRE - Maria Veloso

saia errada. O jornalismo é feito de checagem. Se a gente não checa a informação, vamos deixar de ser jornalistas e vamos virar fofoqueiros (Jornalista da Tribuna do Norte, informação verbal).

Apesar dessa colocação do editor da Tribuna do Norte, os repórteres acreditam que equívocos podem acontecer devido à divisão da atenção entre várias tarefas.

c) Abertura dos canais informacionais:

Trata-se do processo pelo qual as empresas jornalísticas abrem espaço para a colaboração dos seus públicos na construção do conteúdo noticioso, seja a partir de um aplicativo em software, de um espaço no site ou por meio das redes sociais, como WhatsApp, Facebook e Twitter. Assim, modifica-se a hierarquia da produção do conteúdo. Se antes das redes sociais na internet 0 processo de apuração e pesquisa era de responsabilidade total do jornalista, vive-se um período na história do jornalismo em que indivíduos não jornalistas podem alcançar grandes audiências (a chamada "viralização" de informações) quanto os próprios profissionais de mídia. Não se tratam mais de receptores passivos. A interação faz com que sejam emissores e receptores concomitantemente, com postura ativa e tendo a possibilidade de falar para uma grande audiência.

A abertura dos canais comunicacionais facilita ao público o contato com as empresas para sugestões e envio de conteúdos; por outro, reforça aos jornalistas a importância da apuração para a garantia da credibilidade.

Com a abertura dos canais, os jornalistas têm a responsabilidade de selecionar, filtrar e apurar as informações que chegam pelos canais informacionais, de modo a buscar evitar possíveis falhas geradas pela divulgação de conteúdos equivocados. Profissionais de ambas as empresas salientaram a cautela com os conteúdos recebidos do público antes da publicação. Contudo, reconheceram que é árduo manter diligência com os materiais enviados pelos internautas ao mesmo tempo que precisam executar diversas outras atividades em suas rotinas produtivas. 
A gente tenta lidar com essa onda de informações que chega da melhor forma possível. A apuração é a chave do negócio. O problema é que as vezes são tantas informações vindo, com tanta coisa pra fazer, notícia pra escrever, foto pra fazer, que quando outro veículo publica, na pressa de não ficar pra trás, publicamos também e aí acontecem os erros. Outra coisa é confiar na fonte. Já "matamos" uma personalidade aqui de Natal porque confiamos em uma fonte da família dizendo que tinha morrido. Não checamos e era equivocado. Publicamos o erro. Tivemos que pedir desculpas (Jornalista do Novo, informação verbal).

Compreender a dinâmica que envolve a abertura dos canais informacionais é mais um desafio que o jornalismo enfrenta a partir da prática do jornalismo móvel digital. Os jornalistas, enquanto profissionais, receberam outras atribuições com os dispositivos móveis, entre eles alguns próprios de plataformas digitais, como a maior interação com o público e possibilidade deste se colocar ativamente diante dos fatos.

d) Jornalismo de redação:

Trata-se de prática na qual todo o processo de coleta de dados e escrita de um conteúdo jornalístico, em qualquer formato, é realizado pelo jornalista de dentro da própria redação, sem trabalho de campo. O contato com as fontes é realizado por meio de chamadas de voz e/ou entrevistas em redes sociais na internet, e o levantamento e checagem de informações geralmente são realizadas em sites de busca, agências de notícias e/ou banco de dados.

A necessidade de atualização contínua, característica do jornalismo online, dá subsídios para que a complexidade do processo produtivo tradicional - com apuração em campo e realização de entrevistas presenciais - em alguns casos seja substituída pela prioridade à notícia urgente, instantânea, publicada quase que concomitantemente ao acontecimento. Nesse sentido, os smartphones e outros dispositivos móveis exercem um papel importante, apontado pelos jornalistas entrevistados, especialmente, na agilidade da realização de entrevistas.

Se os dados estão na internet e podemos contactar as fontes pelas redes sociais na internet, seria perda de tempo e dos próprios recursos do jornal se o repórter fosse até lá pra obter as mesmas

João Pessoa - Brasil | ANO 8 VOL.8 N.1 | JAN./JUN. 2021 | p. 13 a 31

Revista Latino-americana de Jornalismo | ISSN 2359-375X

Programa de Pós-Graduação em Jornalismo - UFPB

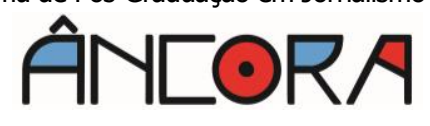




\section{ÂNEORA}

Alice ANDRADE - Itamar NOBRE - Maria Veloso

informações que ele pode ter virtualmente. Não faria o menor sentido. Nesse tempo de crise, é questão de bom senso. Quando dá, fazemos o texto daqui mesmo. Só que nem sempre dá, então quando é preciso ir pra rua, o repórter vai (Jornalista do Novo, informação verbal).

A apuração sem contato presencial com a fonte, por telefone, por exemplo, não é algo recente, no jornalismo diário. Os dispositivos móveis digitais, contudo, ampliaram radicalmente essa prática, que alguns autores associam à figura do "jornalista sentado" (NEVEU, 2001; PEREIRA, 2004).

Segundo Pereira (2004, p.103), "com a internet e o surgimento do 'jornalista sentado', a noção da apuração perde terreno para a necessidade de alimentação contínua do sistema". Ou seja, a investigação jornalística, intrínseca ao processo de trabalho, torna-se virtualizada para que o produto final seja entregue de forma mais célere para o público. Ser proativo na produção e ágil na escrita tornam-se habilidades indispensáveis aos profissionais que ingressam no mercado de trabalho.

\section{Considerações finais}

Afinal, a quem servem as tecnologias móveis? Sob o olhar da dimensão das práticas sociais no jornalismo móvel, esse foi um questionamento que nos guiou ao longo desta reflexão, pois as observações empíricas mostraram sinais, características e apontamentos das modificações pelas quais o jornalismo está passando a partir da intensificação do uso desses aparelhos e suas consequências, tanto para a produção jornalística quanto para os profissionais e o público. Em uma sociedade imersa no ambiente digital e em suas processualidades, o jornalismo e os dispositivos móveis digitais são hoje quase indissociáveis.

Como resposta a tal inquietação, a relação jornalista-empresa-público, potencializada pela ambiência virtual, nos parece gerar consequências que podem ser consideradas favoráveis ou desfavoráveis, de acordo com as conveniências de cada parte: ao jornalista, enquanto ferramenta de trabalho; 
à empresa, como forma de modernização e de contenção das despesas; e ao público, pois através dos DMDs as informações e produtos jornalísticos estão presentes em suas vidas de maneira cada vez mais ubíqua, personalizável e instantânea.

Essa relação reflete na reorganização do processo produtivo jornalístico e na identidade profissional dos jornalistas. Isso porque a busca por inovação, celeridade e produtividade requer dos profissionais requisitos para funções que antes cabiam a outros. Hoje não basta dominar apenas uma linguagem jornalística, visto que as atividades exercidas nas redações abrangem múltiplas funções. Por exemplo: um jornalista do meio impresso, cuja principal função em meados de 1990 era apurar e escrever seus textos, em 2017 também precisa fotografar, gravar vídeos, gerenciar redes sociais e lidar diretamente com as demandas do público.

Há apontamentos favoráveis por parte dos entrevistados acerca da prática do jornalismo móvel digital nas redações, como a agilização do processo produtivo, as potencialidades de novos formatos e iniciativas, a facilitação do contato entre os profissionais e suas fontes, a hibridização de diversas ferramentas em uma única e a possibilidade de conexão à internet. Todavia, nota-se que paralelamente avança um processo de precarização da atividade, pois sob a justificativa da inovação está um profissional que trabalha em praticamente todos os horários do dia, inclusive em momentos particulares de sua vida social; que precisa exercer atividades simultâneas, e deve dominar várias linguagens e modos de transmissão das mensagens, mesmo sem qualificação e remuneração adequadas para tal. E, obviamente, é continuamente cobrado por resultados.

Além disso, a execução simultânea de diferentes atividades pode comprometer a qualidade do produto final, visto que a concentração é dividida entre tarefas sobre as quais nem sempre há domínio significativo, em especial a fotografia e produção de materiais em vídeo.

João Pessoa - Brasil | ANO 8 VOL.8 N.1 | JAN./JUN. 2021 | p. 13 a 31 


\section{ANTERA}

Alice ANDRADE - Itamar NOBRE - Maria Veloso

Apesar da agilidade que proporcionam ao processo de apuração e produção jornalísticos, os dispositivos móveis digitais podem, por outro lado, comprometer a execução de determinadas tarefas, em especial devido ao acúmulo de funções na rotina de trabalho dos profissionais (RODRIGUES, 2009). A característica multitarefa desses aparelhos torna o ecossistema móvel não mais um acessório da prática jornalística, e sim uma realidade desafiadora e ocasionadora de transmutações (SILVA, 2016) no processo de produção e circulação de informações no contexto convergente e de mobilidade do jornalismo.

\section{Referências}

CANAVILHAS, João. Webjornalismo: Da pirâmide invertida à pirâmide deitada. Universidade da Beira Interior, Portugal, 2006. In: BARBOSA, Suzana (Org.). Jornalismo digital de terceira geração. Covilhã: LivrosLabcom, 2006. p. 26-36.

FIDALGO, António; CANAVILHAS, João. Todos os jornais no bolso: pensando na era do celular. In: RODRIGUES, Carla. Jornalismo online: modos de fazer. Rio de Janeiro: Ed. PUC-Rio; Sulina, 2009.

FÍGARO, Roseli. Perfis e discursos de jornalistas no mundo do trabalho. In: FÍGARO, Roseli; NONATO, Cláudia; GROHMANN, Rafael. As mudanças no mundo do trabalho do jornalista. São Paulo: Atlas, 2013.

GOGGIN, Gerard. Cell phone culture: mobile technology in everyday life. New York: Routledge, 2006.

JORGE, Thais de Mendonça; PEREIRA, Paulo Henrique; ADGHIRNI, Zélia Leal. Jornalismo na Internet: desafios e perspectivas do trinômio formação/universidade/mercado. In: RODRIGUES, Carla. Jornalismo online: modos de fazer. Rio de Janeiro: Ed.PUC-Rio; Sulina, 2009. NÉVEU, Erik. Sociologie du journalisme. Paris: La Découverte, 2001. PEREIRA, Fábio Henrique. 0 'jornalista sentado' e a produção da notícia on-line no CorreioWEB. Em Questão, Porto Alegre, v. 10, n. 1, p. 95-108, jan./jun, 2004. Disponível em:

<http://repositorio.unb.br/bitstream/10482/12503/1/ARTIGO_JornalistaSent adoProducao.pdf>. Acesso em: 22 mar. 2021.

QUINN, Stephen. Jornalismo móvel: a última evolução na captação de notícias. Revista Parágrafo, v. 2, n. 2, p. 80-97, 2014. Disponível em: $<$ http://revistaseletronicas.fiamfaam.br/index.php/recicofi/article/view/235/2 64>. Acesso em: 10 mar. 2021. 
RODRIGUES, Carla. Ainda em busca de definições para o jornalismo on-line. In: RODRIGUES, Carla (Org.). Jornalismo on-line: modos de fazer. Rio de Janeiro: Ed. PUC-Rio: Sulina, 2009. p. 13-33.

SALAVERRÍA, Ramon; NEGREDO, Samuel. Periodismo integrado.

Convergencia de médios y reorganización de redacciones. Barcelona:

Editorial Sol90, 2008.

SANTOS, Boaventura de Sousa. A crítica da razão indolente: contra o desperdício da experiência. 8. ed. São Paulo: Cortez, 2011.

SATUF, Ivan. Jornalismo móvel: da prática à investigação acadêmica. In: CANAVILHAS, João; SATUF, Ivan (Org.). Jornalismo para dispositivos móveis: produção, distribuição e consumo. Covilhã: Livros LabCom, 2015. SCOLARI, Carlos. Hipermediaciones: elementos para una teoría de la comunicación digital interactiva. Barcelona: Gedisa, 2008.

SILVA, Fernando Firmino da. Jornalismo móvel digital: o uso das tecnologias móveis digitais e a reconfiguração das rotinas de produção da reportagem de campo. 2013. 408 f. Tese (Doutorado em Comunicação e Culturas Contemporâneas) - Faculdade de Comunicação Social, Universidade Federal da Bahia -UFBA, Salvador, 2013.

SILVA, Fernando Firmino da. Jornalismo móvel. Salvador: EDUFBA, 2015. SILVA, Fernando Firmino da. Transmutações no jornalismo. Campina Grande: EDUEPB, 2016.

SILVERSTONE, Roger. Por que estudar a mídia? São Paulo: Edições Loyola, 2002. 